\title{
The Impact of Agricultural Credit on Rice Productivity
}

\author{
Eko Wicaksono \\ Fiscal Policy Agency, Ministry of Finance of Republic of Indonesia, Jl. Dr. Wahidin 1, Jakarta, 10710, Indonesia \\ E-mail: ewicaksono@fiskal.depkeu.go.id
}

\begin{abstract}
This study investigates the impact of credit access on agriculture productivity in Indonesia using provincial level data. Credit access is deemed to have positive impact on productivity since it provides farmers with resources needed to start the production process. Thus, greater access to credit can induce agriculture production and support government program for food security which is very important for Indonesia, the fourth-largest country in the world in term of population. Indonesian government has given several incentives to broaden the access for agriculture credit. One of the incentives is through the implementation of credit programs either in term of interest rate subsidy or in term of guarantee scheme. Using panel data from 27 provinces between 2001 and 2009, this study finds that credit for agriculture has positive impact on rice productivity. Therefore, this finding suggests that government policy to broaden the access to credit market for farmers is of the keys to implement food security program. Moreover, this study also finds that educating farmers as well as increasing state budget for agricultural sector can be substantial in boosting rice productivity.
\end{abstract}

Keywords — Agricultural credit, agriculture, rice productivity.

\section{INTRODUCTION}

Indonesia is the fourth largest country in the world with more than 250 million of population. The huge number of population can be an advantage since it will give demographic bonus through productive human resources. On the other hand, it also can be an important problem since rapid growth of population will cause significant increase in demand for food, thus leading to food security problem if it is not supported with adequate production of staple food such as rice. The demand for rice always increases over time; meanwhile the domestic supply of rice cannot completely fulfil the upward trend in domestic rice consumption (Figure 1). Both rice production and domestic consumption has been increasing in the period of 2000 to 2011, nevertheless the growth in consumption is a bit over the growth in domestic rice for that period.

The shortage of domestic rice production also can have impact on inflation. Any shortage in the supply of rice can lead to higher inflation since it will drive up the price of rice in the market. According to data on inflation from Central Bureau of Statistics as in [1], food price experiences the highest climb among the other goods. Therefore, sufficient domestic rice production can help the efforts aimed to control inflation.

Indonesian government has implemented several strategies to increase domestic agricultural production such as seeds subsidy, fertilizer subsidy, and credit program.
Those policies are expected to give incentives to domestic production to cope with domestic demand for agriculture products as well as to increase export to improve trade balance. The greater access to credit is expected to help farmers acquire all the inputs needed for the production process. The credit program itself has been implemented since four decades ago with several schemes such as interest rate subsidy and collateral support.

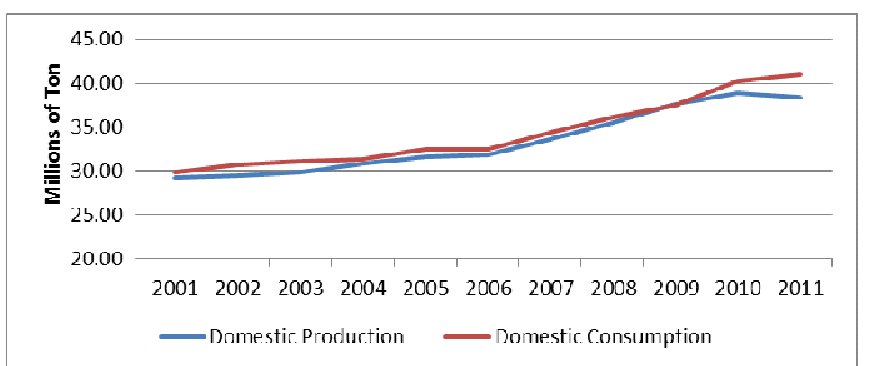

Fig. 1 Domestic rice production vs domestic rice consumption. Source: Ministry of Agriculture

Previous studies have shown that there are both positive and no impacts of credit on agricultural output. Nevertheless, none of the studies have investigated the impact of agricultural credit using provincial level data in Indonesia. This study is aimed to investigate the impact of credit allocated to agricultural sector on the production of rice in Indonesia. The remainder of this paper is structured as follow: section II summarizes the literature review, section 
III describes the data and methodology, section IV explains the results, and section $\mathrm{V}$ concludes.

\section{LITERATURE REVIEW}

Access to credit is deemed as one of the way to improve agricultural sector performance. Farmers can have more resources available to obtain the inputs needed for the production such as seeds, fertilizer, and water. Sufficient number combined with high quality of input is expected to have positive impact on the production of agricultural products, thus leading to either higher production or greater yield.

Nevertheless, previous studies have shown different results regarding the impact of credit on rice production. According to [2] which conducted study in Central Lombok, there are both "positive" and "no" impact of credit on agricultural production. About one half of the respondents stated that they experienced improvement in their production, while the rest of the respondents stated that they experienced no significant improvement on rice production. The improvement in production came through intensification which makes farmers able to apply more fertilizer, seeds, pesticides and better maintenance. Moreover, the availability of credit makes farmers able to practice farming without any delay since they have resources to irrigate their rice field by became less dependent to rainfall.

Reference [3] also mentioned that the main reason for farmers to apply for credit is the lack of capital. In other words, farmers will not borrow money unless they don't have enough resource available to cover production costs. Therefore, credit will be very substantial to sustain rice production in a case where no buffer is available for farmer to start the production.

Reference [4] finds that short-term credit has no impact on farm productivity in Chile; however, they find that other factors such as education and type of activity do have positive impact on productivity. Moreover, they also mention that the impact of credit on productivity will depend on the characteristic of the farmers itself which is whether they are credit-constrained or not. Therefore, in order to capture the effect of credit on farmers, ideally we should consider this characteristic to avoid selection bias.

Reference [5] investigates the determinants of rice production in Pakistan and finds that there is insignificant impact of credit disbursement on rice production. Those with significant impacts on rice production are area under cultivation and water availability. On the other hand, [6] observes the same country and find that institutional credit and water availability have positive impacts on agricultural production. The impact of direct input on production is consistent between those two studies; nevertheless the impact of credit availability on agricultural production, especially rice is still unclear.

The more recent study is conducted in Nigeria by [7] which finds that farmers who have access to credit are associated with better yield and greater profit. Moreover, he also shows that age, education, gender, and contact with extension services are positively correlated with having more access to credit.

Indonesian government had implemented various policies since four decades ago in order to broaden the access to credit for farmers, especially those who are considered as poor farmer. The first program implemented was named Kredit Bimas which was started from 1967 until 1985 and was administered by a stated owned bank, Bank Rakyat Indonesia. The interesting feature of this credit program for farmers was the interest rate subsidy from the government. According to [8], the amount of credit disbursed was Rp 636.7 million for 28.847 borrowers. In the period of $1970-$ $1975,80 \%$ of the loan was well-performed. However, in the period of $1980-1985$, only $57 \%$ of it was settled. The high portion of non-performing loan is attributed to the wrong perception among farmers about the rule of the loan. Farmers considered that they no need to pay back the loan since it was deemed as government assistance for them. Therefore, most of the loans were not paid timely and fully by the farmers. Despite the problem mentioned before, this program was considered a success for agriculture production in Indonesia since the food self-sufficiency could be achieved in 1984. This fact shows that greater access to fund could support farmer to improve the production and support national food security program.

Kredit Bimas program was ended in 1983 and another program which called Kredit Usaha Tani (KUT) was launched two year later. Compared to the former, It had different scheme and feature. First, it was distributed through koperasi unit desa, a small enterprise established by a group of farmers in rural areas. Second, the interest rate on it was quite high compared to Kredit Bimas, since the borrower should pay a $12 \%$ interest on the loan (compared to $3 \%$ interest rate for Kredit Bimas). Reference [8] mentioned that the problem of non-performing loan was still present in the second program. He stated that only $25 \%$ of the loans were fully paid back. Eventually, the program was abandoned in 1999 since central bank of Indonesia was not allowed to distribute Kredit Likuiditas Bank Indonesia (KLBI). Up to its termination date, KUT program were able to distribute Rp 8 trillion of credit.

The government introduced a new program called Kredit Ketahanan Pangan (KKP) to replace KUT. It was begun in 2000 with $\mathrm{Rp} 2.08$ trillion available to disburse to farmers. The program was intended for food crop intensification and food procurement. The specific target of this program was groups of farmers and koperasi. In this particular program, the government subsidized the interest rate. The name of the program was changed to KKP-E in 2007 since the government extended the scope of the program to cover crop production that was intended for biofuel production in order to achieve energy security as well.

Since the former programs faced non-performing loan problem, the banks assigned to distribute the credit become more prudent in assessing their debtor candidates. This condition could minimize the risk of default on loan. On the other hand, it could make the process of credit disbursement from banks to the debtors become slower, thus leading to relatively low absorption of credit program. Moreover, this program also requires the debtors to provide collateral which is greater than the amount of fund that they are going to borrow. Therefore, these conditions on the other side can lead to narrow access to credit, especially for poor farmers who do not have enough assets to collateralize. 
Those previous studies in several countries including Indonesia had shed some lights on the impact of credit on agricultural production. Therefore, I hope that this study can add some value to the previous studies conducted before and also can give more ideas for further studies.

\section{DATA AND METHODOLOGY}

This study employs Indonesian regional data collected by World Bank which is named as "INDO-DAPOER". Those data are meant for policy and economic research in Indonesia. It is collected from various institutions such as Central Bureau of Statistics, Ministry of Finance, and Central Bank of Indonesia. The database contains several important economic and social indicators either at provincial or district level which spans from 1976-2012. The data catalogues as well as the repositories are available at The World Bank website which makes it easy for any researcher to collect comprehensive data.

In order to investigate the impact of agricultural credit on rice productivity, provincial level data are used in this study. Since the data from several provinces are not available, only 27 out of 33 provinces are included in this study. Fixed effects model with dynamic time effect is employed to capture the impact of key variable of interest. The model employed in this study is as follow:

$$
Y_{i t}=\beta_{0}+\beta_{1} X_{1 i t}+X \beta+\alpha_{i}+\lambda_{t}+v_{i t}
$$

$Y_{i t}$ is rice productivity of province $\mathrm{i}$ in year t, $X_{1 i t}$ is natural $\log$ of agricultural credit in province $\mathrm{i}$ in year $\mathrm{t}, X$ is a vector of control variables which includes percentage of agricultural employment, literacy rate and government expenditure for agriculture function. $\alpha_{i}$ is provincial level fixed effects, $\lambda_{t}$ is time effects, and $v_{i t}$ is error term.

Rice productivity is defined as rice production for every hectare field which is stated in 0.1 ton. It is collected from Central Bureau of Statistics. Agricultural credit is the amount of credit distributed for agricultural sector in each province. The previous variables are the key interest variables. The covariates employed in this study are several variables that can affect the rice productivity in provincial level. First, percentage of agricultural employment can affect the level of productivity. The more people employed in agricultural sector is expected to have positive impact on agriculture production. Second, literacy rate can be a proxy of how people in particular area are ready to grasp knowledge. Related to agriculture production, higher literacy rate can have positive impact on agriculture production, since literate farmers are ready to grasp on any new knowledge in farming and apply any new technological development in farming. Therefore, high literacy rate is expected to have positive impact on productivity since by applying technological innovation and new knowledge in farming, more output can be produced using the same amount of input. Third, government expenditure for agricultural function is also expected to have positive impact on agricultural production. More budget allocation for agricultural function reflects government support for agricultural development that should be positively correlated with agricultural productivity. In this study, government expenditure used is the aggregate of government expenditure for agricultural function in each province which includes total city/district level expenditure and province level expenditure

After removing some outliers, there are 217 observations which come from 27 provinces in Indonesia. Several provinces are excluded from the observation since it has no rice production such as DKI Jakarta and some have no quite long series to be included in the sample. The data used in this study is unbalance panel which covers 9 years period from 2001 to 2009.

\section{RESULTS AND DISCUSSIONS}

The complete regression results are shown in Table 1. Two specifications are employed in the regressions and all of them show that credit has statistically significant impact on rice productivity. The coefficient on agricultural credit changes from one specification to another. The first specification which includes agricultural credit, percentage of agricultural employment, literacy rate and agricultural expenditure as the control variables, finds that the impact of agricultural credit is positive and statistically significant. The next specification which includes year dummy as other control variables show that the impact of agricultural credit is always consistent though the magnificent of the coefficients are bit different. The latter includes year dummy to capture the time effect in the model since after taking the test of parameter, it is found that time effect does have significant effect on rice productivity. Time effect can reflect any condition that has affected rice productivity in each year of the observation such as climate condition, economic condition and any policy implemented that may affect rice productivity as well.

TABLE I

The IMPACT Of Agricultural CREDIT ON Rice PRoductivity

\begin{tabular}{|l|c|c|}
\hline VARIABLES & $(1)$ & $(2)$ \\
\hline & & \\
Log of agricultural credit & $1.48^{* * *}$ & $1.23^{* *}$ \\
Percentage of agricultural employment & $(0.410)$ & $(0.443)$ \\
& -2.74 & -0.75 \\
Literacy rate & $(3.238)$ & $(3.470)$ \\
& $0.25^{*}$ & 0.07 \\
Log of agriculture expenditure & $(0.136)$ & $(0.167)$ \\
& $1.59^{* * *}$ & 0.12 \\
Constant & $(0.449)$ & $(0.600)$ \\
& & $(1.514)$ \\
Observations & $-41.26^{* * *}$ & 14.60 \\
R-squared & $(11.089)$ & $(23.005)$ \\
Number of provinces & & \\
\end{tabular}

Robust standard errors in parentheses.

Specification (2) includes year dummy variable $* * * \mathrm{p}<0.01, * * \mathrm{p}<0.05, * \mathrm{p}<0.1$

According to the results, Agricultural credit is found to have positive and statistically significant impact on rice productivity. A $10 \%$ increase in agricultural credit is associated with 1.2 ton per hectare increase in productivity. Therefore, it is consistent with previous study that greater access to credit can induce agricultural productivity. While 
the impact of agriculture credit on productivity is found to be positive; nevertheless no statistically significant impact is found on the rice production. This finding is consistent with [1] which found that credit was more associated with intensification rather than extensification. Having greater access to financing makes it possible for farmers to apply adequate inputs required for the production. Thus, using the same area of field, the farmers are able to produce more rice.

The regression results show that other control variables also have association with rice productivity. Literacy rate have positive impact on rice productivity shown by the specifications, although the impact on the last specification is not statistically significant. Government expenditure for agricultural function is also found to have positive impact on rice productivity. On the other hand, the percentage of agricultural employment has negative correlation with rice productivity. One that can explain this result is that as more labours involved in the production, the total output decrease since each labor contributes less since the marginal product of labor is decreasing, thus leading to less productivity per hectare of field. Nevertheless, the coefficient on it is not statistically significant.

The findings of this study imply that in order to increase domestic production of rice, important factors other than agricultural credit should also be considered. One of them is the change in land use from paddy field into other use such as housing and commercial use. If more rice can be produced using the same area of land, meanwhile on the other hand the total area of field is decreasing, then the effects of those factors will cancel out each other, thus leading to no significant improvement in the production of rice. Therefore a comprehensive policy formulation is a necessity if the government intend to achieve sustainable food security.

According to [9] change in land use does happen since three decades ago. Java is considered as the island where most of the change occurs. It is not surprising since Java is the centre of economic activity in Indonesia even though its soil is considered fertile enough for any crop to grow. Therefore in order to achieve a sustainable food security, an improvement in rice production and several bolstering policies must be implemented simultaneously.

The distribution of credit program for farmers is also cumbersome. The absorption of credit still can be optimized since the realized credit disbursed is still under the amount of allocated budget for credit program. The low absorption of credit program cannot be separated from the experiences of the previous programs such Kredit Bimas, and KUT. The risk of default on loan makes the bank require the farmers to collateralize any asset which value is higher than the amount of the credit proposed. Therefore, access to credit will be enjoyed more by rich farmers instead of poor farmers.

Finally this study is not completely free from caveats. First, the data of agricultural credit employed in this study is not limited to credit used rice production, instead it is also can be used for other crop production or cattle breeding as well. Second, association does not imply causation, thus the finding in this study should be interpreted carefully. A further study with more observations at district level as well as more detail study using data of credit allocation for crops production can confirm the finding of this study.

\section{CONCLUSION}

Several previous studies have found that greater access to credit is associated with better crop productivity. Greater access to credit makes the farmers able to satisfy main inputs needed for production. This study investigates the impact of agricultural credit on rice productivity. Using provincial level data from 2001 to 2009 , it is found that agricultural credit has positive significant impact on rice productivity. A ten percent increase in credit allocated for agriculture sector leads to an increase of 1.2 ton rice produced per hectare of field. Despite positive impact of credit on productivity, there is no significant impact of credit on rice production. This finding is consistent with previous studies which found that agricultural credit is more associated with intensification rather than extensification in farming. Therefore, in order to improve rice production, policies concerning both intensification and extensification should be comprehensively designed.

Finally this study is not completely free from caveats; therefore any finding in this study should be carefully interpreted. Further studies on micro level as well as studies in experimental setting can give a better gauge on the causal effect of agricultural credit on rice productivity.

\section{ACKNOWLEDGEMENT}

I would like to thank to all my colleagues in the Ministry of Finance for all the support during the writing of this paper. Many thanks also for The World Bank team for administering INDO DAPOER which is very valuable for Indonesian researchers. Lastly, this paper should not be reported as representing the views of The Ministry of Finance of Republic of Indonesia. The views represented in this paper are those of the author and does not necessarily represent of those of The Ministry of Finance of Republic of Indonesia.

\section{REFERENCES}

[1] Central Bureau of Statistics website (2014) [Online]. Available: http://www.bps.go.id/tab_sub/view.php?kat=2\&tabel=1\&daftar=1\&i d_subyek $=03 \&$ notab $=1$

[2] T. Sjah, D. Cameron, and I. Russel, "Factors Contributing to The Performance of Agricultural Credit in Lombok Indonesia", Contributed paper presented at $14^{\text {th }}$ IFMA Congress in Perth, , $10^{\text {th }}-$ $15^{\text {th }}$ August 2003.

[3] T. Sjah, I. Russel , and D. Cameron, "Acceptance and Repayment of Agricultural Credit in Lombok Indonesia", Contributed paper presented at $14^{\text {th }}$ IFMA Congress in Perth, $10^{\text {th }}-15^{\text {th }}$ August 2003.

[4] A. Reyes, R. Lensink, A. Kuyvenhoven, and H. Moll, "Impact of Access to Credit on Farm Productivity of Fruit and Vegetable Growers on Chile", Selected poster presented at The International Association of Agricultural Economists (IAAE), Foz do Iguacu, Brazil, 18-24 August 2012.

[5] A. Hussain, "Impact of Credit Disbursement, Area Under Cultivation, Fertilizer Consumption, and Water Availability on Rice Production in Pakistan (1988-2010)", Sarhad Journal of Agriculture, vol. 28, no.1, 2012.

[6] M.H. Sial, M.S. Awan, and M. Waqas, "Institutional Credit and Agricultural Production Nexus", MRPA Paper, no. 30932, posted on $24^{\text {th }}$ June 2012.

[7] S.O. Akinbode, "Access to Credit: Implication for Sustainable Rice Production in Nigeria", Journal of Sustainable Development in Africa, vol. 15, no.1, 2013.

[8] Anshari, "Policy Optimization of Credit Program for Agricultural Sector in Indonesia", Analisis Kebijakan Pertanian, vol. 7, no. 1, March 2009.

[9] Wahyunto, "Paddy Fields in Indonesia As A Back Stopped for National Food Security”, Informatika Pertanian, vol. 18, no.2, 2009. 